\title{
The Yahwenomics of Land and Social Justice and Contemporary Land Resource Crises In Nigeria.
}

\author{
Rev. Cephas T. A. Tushima, Ph.D. \\ Associate Professor of Biblical Studies \& Deputy Provost for Academic Affairs (Jos ECWA Theological \\ Seminary), Research Fellow (University of South Africa, UNISA), Research Associate (Stellenbosch University); \\ and Fulbright Scholar-in-Residence, Geneva College (PA, USA).
}

\begin{abstract}
This paper examines the Torah and prophetic understanding of Yahweh's economics of land ownership and management and its social justice implications within the covenant community of the Israel. Similarly, the paper also surveys the Nigerian land administrative practices. As a contextual study, it then correlates the biblical perspectives with the contemporary realities of land resource crises and their concomitant communal conflicts in Nigeria. The paper also highlights the elements of contextual connexity between the biblical patterns of land economy and justice vis-à-vis the Nigerian situation. Consequently, inferences are drawn from the Yahwenomics of land and social justice for the development of a just and equitable land policy and administration in Nigeria.
\end{abstract}

Key words: Land economy, land grab, land tenure, land holding, land administration, Land Use Act, Tiv, Ibo, Fulani, social justice, colonial administration.

\section{INTRODUCTION}

The English word "Land," in the biblical (Hebrew Bible) sense, is predominantly a translation of either

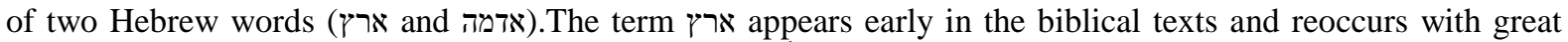
frequency (occurring 2,505 times in the Hebrew Bible ${ }^{1}$ ), highlighting the significance of the term in biblical thought. The uses of are cosmological (in reference to the whole earth, cf. Gen 1:1-2), geographical (in reference to a physical land mass, cf. Gen 2:12; 4:16; 11:2; Psa 27:13), territorial (in reference to a geo-political entity, Gen $2: 13 ; 10: 5,10-11,20 ; 32: 49)$. Less frequent in occurrence is wדמה, which is used regularly with the ארץ has the combined sense of both physical land mass as well as territory (cf. Deut 3:18; 4:1; 6:3).

As moderns, land to us is valued, as a physical feature, for its economic utility more than anything else. For the ancients, "the concept of land combines geography and theology. ... from the outset, human beings and the earth ('erets) functioned in a symbiotic relationship with the Creator (Gen 1:28)." ${ }^{2}$ For ancient Israel, in particular, the Promised Land was premised on the sanctuary prototype of Eden (Gen 13:10; Deut 6:3; 31:20). ${ }^{3}$ In biblical creation account, the origin of this intricate relationship is sketched out, and humanity is enthroned as God's vicegerent (steward) over creation. What obtained on the cosmic plane of the whole earth (Gen 1:26-28), was replicated even at the small scale of land as a parcel of physical territory (the Garden of Eden), where humanity was "given the privilege to rule and the responsibility to care for this garden under the sovereignty of their divine Lord." "Thus, in her religiosity, Israel developed a comprehensive theology of land (in the Torah, especially in the book of Deuteronomy) that intricately weaves the motifs of land, economy, and justice with her relationship with YHWH.

In this contextual study, I will be exploring the above relationships in this paper, and then inquiring into their significance for land related problems of contemporary Nigeria. This line of thinking is considered appropriate in view of the foundational nature of Deuteronomic theology in biblical thought. The strong sense of covenantal community (brotherhood) in the Deuteronomic conception of the people was anticipatory of the new covenant people of God. We subscribe to C. H. Wildberger's position that as Christians, our understanding of our dual position as earthly pilgrims and heavenly citizens has not forestalled "the necessity for an approach to

${ }^{1}$ The Baker Illustrated Bible Dictionary, (subsequently TBIBD; ed. Tremper Longman III; Grand Rapids: Baker, 2013), 464. Indeed, the TBIBD observes that $12.42 \%$ of the occurrences of ארץ are in Genesis.

${ }^{2} T B I B D, 464$.

${ }^{3} T B I B D, 464$.

${ }^{4}$ Sandra Richter, Environmental law in Deuteronomy: One Lens on a Biblical Theology of Creation Care," BBR 20:3 (2010): 356. 
our present existence on the land where God has put us and, therefore, the use of land and property during our short stay here, particularly insofar as this affects both our present neighbor and our future posterity."

\section{YAHWEH, LAND, ECONOMY, AND ISRAEL}

As noted above, at creation, Adam had a unique relationship with God. The earth (particularly the Garden of Eden) was the sanctuary, where God met with the man and his wife. Subsequent to the fall, every divine attempt to walk with humanity universally ended in a fiasco (Gen 4, 6, 11). God decided to choose one man, Abram, and his family, and to commit himself to them for the universal good of all humankind (Gen 12:13). Through Abraham, Israel emerged as the one nation with the unique relationship to YHWH, thereby becoming heirs to the promise of the land made to the patriarchs (Gen 12:7; 13:7; 15:18; 17:8; 26:3-4; 28:4, 1314; 35:11-12). On account of this relationship, Israel was reckoned as YHWH's son (Exod 4:22; Deut 14:1; 32:6; Isa 1:2; Hos 1:10). Just as Israel was YHWH's son, the land also belonged to him by right as Creator, which he bequeathed to Israel as the heir to the promise. Throughout the Torah and beyond, emphasis is made on the divine bequeathal of the land to Israel (Exod 6:4, 8; 12:25; Lev 14:34; 20:24; Num 15:2; Deut 1:8; 4:1, $38 ; 7: 13 ; 12: 1 ;$ Josh $8: 1 ; 9: 24)$. A number of the covenant renewal rituals Israel was to execute upon entry into the land, equally stressed this fact. A good example of this is the Ebal ritual as outline in Deut 27:1-26. It is common knowledge that the structure of Deuteronomy, as a book, approximates that of ancient Near Eastern treaties. The best known dominant types of treaty documents common in the ancient Near East are vassal treaties (the best example of which is the Hittite vassal treaty form) and the royal land grant (typified by the Babylonian Kudurru) ${ }^{6}$

While Deuteronomy as whole is known to take the form of the vassal-suzerain structure, Hill holds that the Ebal ritual was the "Hebrew variation of the ancient Near Eastern land-grant ceremony distinct from and yet integrally related to Israel's entire covenant-renewal experience. As such it is really a ceremony within a ceremony and should be considered the concluding section of the stipulations for covenant renewal in Deuteronomy 12-26." ${ }^{, 7}$ Earlier in the Exodus journey, YHWH had given Israel purity laws she needed to observe in order to persevere in the land (Lev 18:1-30), the opposite of which constituted the abominable offences the Canaanites had committed and resulted in their being devoted for destruction. In the concluding part of this covenant renewal, the land-grant format is used to reiterate these purity laws to ensure a successful tenure in the land. Thus, "Israel's filial sonship with Yahweh and Israel's land tenure" was the basis of Yahweh's solidarity with the nation, ${ }^{8}$ such that when the relationship was kept rightly, it resulted in the tight relational triangulation of YHWH, Israel and land for Israel's benefit.

From early in the Exodus journey, the framework of YHWH's covenant justice economy is sketched out in the Covenant Code (Exod 22:21-27), forbidding the oppression of the most vulnerable members of the community (represented by the alien, the widow, and the orphan). Similarly, usury was also outlawed, and for the poor, a cloak collected as loan collateral was to be returned before nightfall. Likewise the Sabbath year law was instituted so the poor could gather from that which grew of itself in the fields and so the wild animals will also feed therefrom, but also that the land itself may lie fallow to be renewed (Exod 23:10-12). What is said of the seventh year applies to a lesser degree to the seventh day as well.

With regards to land within the economy of YHWH's people, strict legislation was already in place in the priestly code. Leviticus 25 opens with a reiteration of the Sabbath year in which the land was to be left fallow, and what grew on it of itself the owner would share with his servants, the sojourner, his animals, and the wild beasts - a re-echo of the creational mandate of caring for creation (cf. vv. 1-7). The verses that follow (vv. 8-17) outline the provisions for the year of jubilee in which Israelites and all Israelite lands were to be released from servitude. Since both the people and the land belonged to YHWH, they could not be commoditified. On this motif, Cephas T. A. Tushima writes,

The land itself was reckoned as a fief that Yahweh had bequeathed to Israel (Lev 25:23; 2 Chron 7:20;

Ps 85:1). Thus, each individual family land was viewed as Yahweh's inheritance (Hos 9:3; Joel 2:18; $3: 2$; Isa 8:8), for which Israel was just a steward. Therefore, land as Israel's inheritance, was not subject

${ }^{5}$ C. H. Wildberger, "Israel un Sein Land," EvTh XVII (1956): 420-22, as cited in Patrick D. Miller, Jr., "The Gift of God: The Deuteronomic Theology of the Land," Int 23 (1969: 462.

${ }^{6} \mathrm{M}$. Weinfeld, "The Covenant of Grant in the Old Testament and the Ancient Near East," JAOS 90 (1970): 184-203, as cited by Andrew E. Hill, “"The Ebal Ceremony as Hebrew Land Grant?" Journal of The Evangelical Theological Society 31/4 (December 1988): 401.

${ }^{7}$ Hill, "The Ebal Ceremony as Hebrew Land Grant?" 400.

${ }^{8} T B I B D, 465$. 
to a perpetual transfer outside of the family, clan, or tribal allotment (cf. Num 27:7-11; 36:1-12; 1 Kgs 21:1-3; Ezek 46:18). ${ }^{9}$

Thus, transactions in land matters were never meant to result in permanent alienation from the land (especially in the rural areas); the land itself was never to be sold. Any transaction on the land was meant to offer the buyer the value of what the land could produce and not the land itself. By the year of jubilee all lands reverted to the father's house to which they belonged (Lev 25:10-13). In such transactions, both the seller and the buyer were prohibited from taking undue advantage of each other through lying or cheating (Lev 25:14-17). Property in the urban areas was rated differently. For urban lands, once sold, the buyer had just one year within which to redeem the article thus sold, otherwise it became the buyer's property for ever.

\section{LAND, ECONOMY, AND SOCIAL JUSTICE IN ISRAEL}

The covenant book of Deuteronomy has made much of the economic implications of life in the covenant community (regarding horizontal relations among fellow Israelites) as it does concerning cultic purity in Israel's (vertical) relationship to YHWH. The redactional history of the book is well documented and one forebears rehearsing it here. Zipporah G. Glass, along with Ernest Nicholson, puts forward the position that parts of Deuteronomy "emerged in northern Israel during the eighth century BCE, making the prevailing economic conditions the backdrop to the development of portions of the book." ${ }^{, 10} \mathrm{Be}$ that as it may, we know that the eight century BCE was a period of great paradoxes in the life of Israel and Judah. Within the reigns of Jeroboam II (in the northern kingdom of Israel) and Uzziah (in Judah) both kingdoms experienced unprecedented prosperity since the time of David and Solomon. ${ }^{11}$ The absence of military threat and the blossoming of commerce gave vent to the quest for acquisition of wealth and material possessions. Such preoccupation with the pursuit of wealth was concomitant with moral and religious decay and struck hard at the traditional covenant concept of social justice, ${ }^{12}$ hence the need to revisit such themes in the fiery oracles of Amos. Upward advance in socio-economic status invariably comes with a lust for more. Consequently, there emerges an inert self-centeredness that results in exploitation of the weakest elements of the society for the further advancement of those already privileged. The greed of the emergent urban elites of ancient Israel raptured the Israelite society of shared economic burdens through the kinsman redeemer system. As the prophet Amos shows, this bad situation was further exacerbated by the use of increased economic and political power in fraudulent business practices, unjust taxation, and injustices in the judicial system (Amos 2:6-8; 5:7-12; 8:1-6) to boost phenomenally the wealth of the wealthy while reducing the poor to abysmal penury, thereby making the latter perpetually enslaved in indentured servitude in fragrant violation of established traditions.

The strident demands for justice in Israel's covenant documents stand out as unique within the ancient Near East. It is pertinent to note with Norbert Lohfink that the Torah is foundational to the Bible, while the Decalogue constitutes the skeletal structure on which the Torah was build. Generalizing on this premise he points out, "in every society it is the law which gives shape to the world: they define what can be expected; they decide between a thousand alternatives of possible worlds, and they create the one world of any specific society." ${ }^{13}$ The ancient Near East generally shared a lofty moral consensus concerning the maintenance of a just society. As manifested in the extant inscriptions of these ancient societies, the ethic emphasizing the care of the poor was much more pervasive in the ethical consciousness of those societies than our contemporary societies. ${ }^{14}$ Notwithstanding, Israel's approach to the issue surpassed all others that preceded her.

\footnotetext{
${ }^{9}$ Cephas T. A. Tushima, The Fate of Saul's Progeny in the Reign of David (Eugene, OR.: Pickwick Publications, 2011), 2.

${ }^{10}$ Zipporah G. Glass ("Land, Slave Labor and Law: Engaging Ancient Israel's Economy" JSOT 91 (2000): 28) makes this point while drawing on E. Nicholson's Deuteronomy and Tradition (Philadelphia: Fortress Press, 1967, 69).

${ }^{11}$ The dawn of the eighth century ushered in a new lease of life for the northern kingdom. In 802 B. C. the Assyrians under Adad-Nirari III crushed Damascus thereby ending Syria's subjugation of Israel. About the same time Egypt was also weakened by internal troubles so that it could not venture into Palestine. Jeroboam II, therefore, was able to recover much of the territory that Syria had previously seized from Israel (cf. 2 Kg. 14:28) (Thomas Edward McComiskey, "Amos: Introduction and Commentary," 267-331 in The Bible Expositor's Bible Commentary, vol. 7 of 12 vols., ed. Frank E. Gaebelein [Grand Rapids: Zondervan Publishing House, 1985], 269).

12 R. K. Harrison, Introduction to the Old Testament, (Grand Rapids: Eerdmans Publishing Company, 1969), 885.

${ }^{13}$ Norbert Lohfink, S.J., "Poverty in the Laws of the Ancient Near East and of the Bible," Theological Studies 52 (1991): 34-50 [34].

${ }^{14}$ Lohfink, "Poverty in the Laws of the Ancient Near East," 35. 
From Egypt to Mesopotamia, the inscriptions of these ancients made much of the care of the disadvantaged segments of their populations. The curious matter is being able to determine whether much talk about providing justice for the poor and socio-economic action for the weak was only part of royal propaganda or reality. It is rather unfortunate that the former appears to be case rather than the latter. As Lohfink observes, much of the discourse on this motif in Mesopotamian laws tends to occupy the liminal spaces of prologues and epilogues without ever featuring in the core of the law codes themselves. "The prologues and the epilogues outline a world in which everything aims at caring for the poor," but the irony of the situation, Lohfink points out, is that the laws at their core do not even mention the poor, "[ $t$ ]he law simply passes over poverty in silence." 15 This is where the genius and the distinction of Yahwistic Torah shine through: it does not only propose to legislate against the oppression of the poor and powerless, it actually does - it is matter-of-factly truthful as opposed to the mendacity of the Mesopotamian codes.

Vociferous advocacy for the liberation of the disadvantaged and oppressed in society in the earlier parts of the Torah (such as Exodus) eventuates into legislative activism for the creation of a covenant justice community in Deuteronomy (cf. Deut1:15-17; 10:17-18; 14:18-29; 16:18-20; 24:16-18; 25:13-16; 27:19). Israel, having experienced the viciousness of oppression and servitude, was liberated from Egypt and was being led on its way to the Promised Land (Canaan). Life in the Promised Land, when lived in obedience to YHWH's Torah was promised to be a wonder and exemplar for the nations round about Israel (Deut 4:5-8; 26:16-19; 28:1-10). Affirming the kind of justice society prescribed for Israel in Deuteronomy, Pekka Pitkänen notes that besides the unity between the Pentateuch and the Latter Prophets, "archaeological record from the Early Iron Age speaks for an egalitarian society," which gives way, sadly, to social stratification in the Iron Age II ${ }^{16}$ (with the rise of the monarchy).

As we transition to focus on land resources crises in Nigeria (Africa), it is pertinent to recall that as pointed out above, the threefold motif of YHWH-his people-land pervades all of the Torah. In Gen 1 it is found reflected in the relationship between the triad of the Almighty-the cosmos-humanity. Then it moves from that cosmic level to the territorial plane with YHWH-Eden-Humanity (Adam \& Eve), where Eden assumes the dimensions of a sanctuary. As the story unfolds, the triad evolves into YHWH-the Promised Land-Abram (and his family). It is this latest form of the triad that beginning from the Exodus-event metamorphosed into a new triad of YHWH-the Promised Land-Israel. In Deuteronomy, this triad is viewed purely in covenantal terms. Israel's faithfulness to YHWH will result in her enjoyment of the latter's bequeathed Promised Land. Entering the land was only going to be the beginning point of the existential journey with YHWH; Israel's continued existence in the land and enjoyment of it was entirely contingent on her relationship with YHWH. Patrick Miller rightly observes that the ethical and theological construction where "God, land, and people are interrelated in Deuteronomy has significance and validity beyond the historical experience of ancient Israel in Palestine." 17

In exploring the implications or significance of Deuteronomic theology (of land) for contemporary Christians, one needs to keep in view that a number of Deuteronomic themes run as threads through the retelling of the magnolia Dei in biblical redemptive history. The central Deuteronomic theological affirmation about the land, as Miller observes, is that it is the gift of God. Indeed, the Deuteronomists mince no words in proclaiming that Israel's "acquisition and possession of the land rest on no prior claims of sequence of generation or blood relationship, nor on any just deserts (9:4 ff.) because of her size or her conduct as a people." 18 This is sovereign elective grace in operation, which finds its ultimate consummation in the greatest of God's saving acts in history, the Christ-event. Secondly, YHWH's bequeathal of the land was in fulfillment of the promise made to Israel's ancestors (the patriarchs). Specifically, there are eighteen references to the promise of the land to the fathers. ${ }^{19}$ Thus the twin important salvation history themes of grace and promise come together here in Deuteronomy as well. Besides, the connection to the fathers is a motif that spans the entire biblical spectrum into the New Testament, as attested in key New Testament passages such as the genealogies associated with the birth narratives of Jesus, both in Matthew and Luke, and in other passages such as Gal 3:7, 16-29; Rom 4:11$21 ; 9: 7-8$.

The salvation that the believer in Christ experiences surpasses but never obliterate the this-worldly implications of the Torah for contemporary communities of faith, as Jesus said, we are not of this world, but we are in it all the same. This requires, then, an appropriate stance of the citizens of the heavenly city, sojourning on

${ }^{15}$ Lohfink, "Poverty in the Laws of the Ancient Near East," 37.

16PekkaPitkänen, "Dr. Jekyll and Mr. Hyde? Deuteronomy and the Rights of Indigenous Peoples,"

Political Theology 11.3 (2010): 399-409 [400].

17 Patrick Miller, "The Gift of God: The Deuteronomic Theology of the Land," Int 23 (1969): 45165 [453].

${ }^{18}$ Miller, "The Gift of God," 453.

${ }^{19}$ Miller list the passages in Deuteronomy where these reference occur as Deut $1: 8,35 ; 6: 10,18$, 23; 7:13;8:1; 9:5; 10:11; 11:9,21;19:8;26:3, 15; 28:11; 30:20;31:7; 34:4 ("The Gift of God," 454). 
earth, that orients them toward fulfilling the just demands of God for just living, knowing fully well that the property right of one person may have implications for the fundamental human rights of another, just as one person's land ownership may not be unconnected with another's landlessness. Miller powerfully captures these sentiments as he writes, "But the Christian understanding of a pilgrim existence on earth and a citizenship in heaven has not obviated the necessity for an approach to our present existence on the land where God has put us and, therefore, the use of land and property during our short stay here, particularly insofar as this affects both our present neighbor and our future posterity." 20

IV.

\section{PERSPECTIVES ON LAND ECONOMY CRISES AND INJUSTICE IN NIGERIA A Survey of African Perspectives on Landholding}

Land, in Nigeria (like in any other African society), is highly valued. In traditional societies, its significance is first and foremost spiritual. In the metaphysics of the Tiv of central Nigeria, for instance, God rank first above all else, land second, and then the spirits and witches (and wizards) come third. In their conception, for example, the life that God gives, the land receives at death. God gives a child who grows to adulthood (or not) and upon death is received by the land. Land serves, therefore, as the abode of both the living and the dead, and it likewise provides, through the various agricultural practices, the means of sustenance of the living, the dead, and the spirits (via the sacrifices made to them regularly). Writing on the importance of land among the Agila people of Benue State Pita Ogaba Agbese writes,

Land is viewed as the most valuable economic commodity. As in other African communities, the people of Agila attach spiritual importance to the land. It is worshiped through the earth goddess Aje. Land is viewed as the primary sustainer of life and as the final repository of the human body after death. As a result of the spiritual importance attached to it, conflicts over land assume spiritual dimensions. Such disputes are more volatile and also less amenable to quick resolutions. ${ }^{21}$

The spiritual conception of land by Africans, while not exactly the same, parallels the spiritual dimension of the intricate triad connections of YHWH-Humanity(Adam, Abraham or Israel)-Land (the cosmos, Eden or Canaan).

Another important matter that requires attention here is land ownership. The communal ownership of land in traditional African societies is globally acknowledged. J. A. K. Kandawire observes that of the many rights to land two stand out. "First, there is the right to land. In much of traditional Africa this right is not normally vested in individuals but in the group to which these individuals belong. Second, there is the right to use land in perpetuity and this right is vested in individual persons in the group." ${ }^{22}$ Kandawire, however, points out that there is a complex dynamic of relations between the ownership of the group and the possession of individual members of the group that manifest sublime contradictions between converging hierarchy and linear segmentation. He writes,

It is important to note the unifying contradiction in the distribution of rights in land in much of Africa. The contradiction lies in the fact that the ideology of Africans generally stresses the supremacy of the group over its individual members, yet these individuals possess pieces of land as long as they identify themselves with the group. Hence, at the level of fact it would appear as if individuals own land while at the level of ideas it is the group which owns land. ${ }^{23}$

Writing on Ibo land tenure system, Obioha echoes the communal ownership aspects and kinsmen always had the final say on land matters. This he observes was changed with advent of the British colonialists. ${ }^{24}$ A similar

${ }^{20}$ Miller, "The Gift of God," 462.

${ }^{21}$ Pita Ogaba Agbese, "Ethnic Conflict and Hometown Associations: An Analysis of the Experience of the Agila," Africa Today43: 2 (Apr-Jun96), 139-53 [144]. On a similar note, Emeka E. Obioha points that land used to have religious, cultural and political meaning amongst the Ibo people of southeastern Nigeria in the pre-colonial era. However, the westernization of Ibo society through the colonial experience has resulted many changes in its land tenure system, although reminisces of the old customs still subsists ("Change in Tenure Pattern and Customary Land Practices among Igbo Community in Southeastern Nigeria," Anthropologist 10:1 (2008): 45-53.)

22 J. A. K. Kandawire, "Thangata in Pre-colonial and Colonial Systems of Land Tenure in Southern Malawi with Special Reference to Chingale," Africa 47:2 (1977): 185-91 [186].

${ }^{23}$ Kandawire, "Thangata in Pre-colonial and Colonial Systems of Land Tenure," 186.

${ }^{24}$ Commenting further on the continue impact of colonial rule on customary laws (especially land ownership practices), Obioha writes, "Like the customary land laws, other aspects of the social systems of different African societies are undergoing a process of change. With particular reference to the AwoIdemili, the study area, it is important at this juncture to note that the traditional cultures were the 
pattern is observes amongst the ethnic nationalities of central Nigeria. James Abogun rightly notes that "Land tenure system in these localities place ownership on communities or lineage." 25

The hierarchy of traditional land ownership has different layers of operating. From my personal observations of how it operates in traditional Tiv society, one can say that at the lowest rung of the hierarchy, land is owned by a family (with several households in it) and its use is moderated by the head of the family for the benefit of all members of the different households therein. And indeed, individual households lay special exclusive claims to specific landholdings that they use within the ownership context of the extended family. At the next level, land belongs to the kinship or lineage line consisting of several extended families, which share a common ancestry. Such ownership systems follow the various tiers of political administration to the national level of the tribe. This is what Glenn Davis Stone terms genealogical hierarchy. On the Tiv genealogical hierarchy Stone writes, "The Tiv population was organized in a segmented hierarchy, with each segment occupying its own territory, or tar. All of Tivland (Tar Tiv) was divided into nested tars, with each minimal segment's tar abutting the tar of a sibling's minimal segment. To expand, one cleared a new farm on land of the most distantly related neighbor" and if such expansion was met with resistance the person was assured of the support of his largest possible segment group up to the relevant hierarchy whether it was in disputations, litigations, or outright fighting. ${ }^{26}$ Therefore, members of each tier would protect their ownership of the land against perceived outsiders.

The Agila people present another example of the communal implications of landholdings. Agbese explains this phenomenon thus,

Communal land ownership is politically relevant because it transforms every dispute over land between Agila and its neighbors into a communal dispute. When individual Igbos encroach on Agila land, the encroachment is seen through the prism of communal land ownership as a threat to the Agila community as a whole. Accordingly, land encroachment is not interpreted as an isolated incident but as a collective assault by the Igbo community against the people of Agila. ${ }^{27}$

This perception of land ownership explains why on border areas of differing communities or ethnicities, conflict over land between two individuals on either sides of the border could escalate into communal clashes, because the loss of the land belonging to that individual (or family) would represent a loss to the entire community or tribe. This accounts for the reaction of the late Tor Tiv (the paramount ruler of the Tiv people) against the decision of the Federal Government of Nigeria take land from the minority tribes of central Nigeria and create grazing reserve for the Fulani, who have been waging scourged earth wars against these minority tribes with the goal of taking over their lands in the last two decades. In that reaction the late Tor Tiv, Orchivirigh Alfred AkaweTorkula, is reported to have said,

Within my powers, I will not concede one inch of Tiv land for grazing reserves or grazing routes. My subjects are farmers and they need the land to farm. In modern times, and globally, those investing in cattle acquire lands for ranches. They then source for food for their cattle. This solves a lot of conflicts. ... Farming is our occupation and we don't even have enough land. Tiv lands in Taraba and Nasarawa States are gradually being taken over. They still want us to give up the little land we have left for grazing. That is too much to ask; it is unacceptable. ${ }^{28}$

This concern to keep tribal land within the tribe rather than transfer it to other tribes again corresponds to the ethos of tribal land allotment and ownership amongst the Israelite tribes, as represented in Moses' amendment to YHWH's verdict concerning the suit brought to Moses by the daughters of Zelophehad, wherein YHWH had prescribed that if a dead man's heirs were only daughters they should inherit their father's estate, just as sons would have (Num 27:1-11). Moses' amendment to YHWH's verdict was in response to the concerns of the leading men of Gilead, that their allotment might end up being transferred to another tribe through marriage of daughters who inherited their father's land. Moses' amendment required daughters who inherited lands to marry within their tribe so as to keep tribal land allotment within the tribe (Num 36:1-12).

subject and victim of colonial rule, while, the contemporary practices and cultural traits are the products of the ensuing contact" ("Change in Tenure Pattern," 46).

${ }^{25}$ James Abogun, "The Middle Belt People of Nigeria," online at: http://www.the-

nigeria.com/2011/11/middle-belt-people-of-nigeria.html\#.VHqXtTHF8mM accessed 30/11/2014.

${ }^{26}$ Glenn Davis Stone, "'Predatory Sedentism': Intimidation and Intensification in the Nigerian

Savanna," Human Ecology 25: 2 (1997): 223-242.

${ }^{27}$ Agbese, "Ethnic Conflict and Hometown Associations," 144.

${ }^{28}$ Hope Abah, "Tiv Will Not Release Land for Cattle Grazing Reserves-Tor Tiv," Daily Trust

Newspaper, Monday April 28, 2014, Online at: http://www.dailytrust.com.ng/daily/news/22638-tivswill-not-release-land-for-grazing-reserves-tor-tiv accessed on 02/12/14.

DOI: $10.9790 / 0837-2109123850 \quad$ www.iosrjournals.org $\quad 43 \mid$ Page


Non-transference of land outside of the tribe has implications for land sale. In many traditional African societies, land could not be alienated. ${ }^{29}$ It could be loaned out, pledge, or leased, but not transferred permanently to an outsider. With respect to the Awo-Idemili people, Obioha observes that one of the significant changes in land tenure system is the permanent transferability of land in the contemporary era, contrary to customary laws. ${ }^{30}$ In customary land regulation (prior to the advent of the impact of English Common Law), all forms of land deals in most of Africa did not envisage permanent transference or alienation. Implicit in all land deals was temporality. Thus, immigrants (from one community into another) were allowed the use of land (that often had semblances of ownership). The indigenous owners would often reclaim their land on two major counts (besides many other reasons): One, increasing pressure on land demand due to population increase; and two, anytime the "strangers" began to assert their own identities distinct from that of the host community (since land is own by the homogeneous community). These factors account for the land conflict crises in northern Ghana between the host community of Sisala and the immigrant population of Dagara. ${ }^{31}$ It is also a major source of the perennial struggle between the indigenous peoples of Plateau state of central Nigeria and the Hausa-Fulani settlers on the plateau. This traditional Africa conception of non-permanency of land transference accords with the Torah position of land with respect to those within the covenant community, whereby all alienated lands revert to their original owners in the year of Jubilee (cf. Lev 25:10; 27:24).

\section{EVOLVING LAND TENURE SYSTEMS IN NIGERIA}

Land tenure systems in Africa have had a chequered history. Prior to the advent of either Islam or colonial administrations, sub-Saharan Africa had held to a communitarian tenural system, which approximated our description above. In Nigeria, for example, the establishment of the Sokoto Caliphate (over the original Hausa empires - the Hausa Bakwai as well as the Banza Bakwai-secondary [conquered] empires) in the early 1800s saw the usurpation of land ownership from communitarian holding. The sultanate or its representative emirates subsequently laid claims to the control of land (through its Maliki law) rather than local communities.

Colonial administrations at first had conceived the African communitarian landholdings to be primitive. On this, Pauline E. Peters writes, "At first, colonial officials and missionaries, premising a universal 'natural evolution' from 'communal' holdings 'leading up to individual ownership ... traced in every civilization' (Lugard 1922 in Chanock 1991b: 69), considered the African landholding systems backward and in need of change." 32 It was on this premise that at the annexure of Lagos as a colony of the British Empire in 1861, the private land ownership of the English freehold was established in the colony.

In the northern protectorate, the British colonial administration, having adopted the indirect rule as its system of governance and following the pattern of the Caliphate's Maliki law, invariably embraced the state control of land. Through an Ordinance promulgated in 1910, all lands in the northern Nigeria were vested in the governor of the protectorate. ${ }^{33}$ However, in the indirect rule systems, the lands were vested in the traditional chiefs, in this case, the emirs under the Sokoto Caliphate. Thus, the colonial administration imposed the caliphate's Maliki law on the northern minorities. ${ }^{34}$ Consequently, their lands which had been run under lineage holding systems were now part of the estate of the caliphate. This was the beginning of the oppression of northern minorities by their overloads, as imposed by the British colonial administration. The plight of the minorities of southern Kaduna under the Zaria emirate is a perfect case in point.

For the southern protectorate, the colonial administration recognized that,

[L]and was owned by lineages or extended families. Individuals have only right of use on such family land. The only land held at the Governor's disposal was that which had been expressly acquired for

${ }^{29}$ Akin L. Mabogunje, "Land Reform in Nigeria: Progress, Problems \& Prospects," a Paper

Presented to the Presidential Technical Committee for Land Reform, Abuja (2009), 3-4.

${ }^{30}$ Obioha, "Change in Tenure Pattern and Customary Land Practices," 49-50.

${ }^{31}$ Carola Lentz, "Is Land Inalienable? Historical and Current Debates on Land Transfers in Northern Ghana," Africa 80:1 (2010): 56-80.

32Pauline E. Peters, "Conflicts over Land and Threats to Customary Tenure in Africa Today," CID Working Paper No. 247 Sept 2012 (Working Papers Series of Center for International Development at Harvard University).

${ }^{33}$ Akin L. Mabogunje, "Land Reform in Nigeria," 2.

${ }^{34}$ Commenting on these trends in British colonial administration, Peters writes, "The imposition of colonial rule, itself based on ideas of territorial sovereignty, and the consequent fixing of territorial boundaries over which the traditional authorities were made 'trustees', greatly reinforced the link between political authority and authority over land. The formation of customary law shifted authority over land upwards, from family heads, lineage elders, and town chiefs to 'paramount' or 'territorial' chiefs" ("Conflicts over Land," 4). It was this upward mobility of authority over land in northern Nigeria that made the northern minorities endangered species under the emirates of the Sokoto Caliphate. 
public purposes as Crown land. The only control imposed by law on the lineages and other local landholders was an obligation to seek the consent of Government when rights are being conveyed to aliens. $^{35}$

Thus, there were three land tenure systems operating concurrently in Nigeria during the colonial era. These tenural systems subsisted until they were supplanted by the Land Use Decree of 1977 of the Gen Obasanjo led military dictatorship.

A number of factors had led to the promulgation of the Land Use Decree. Mabogunje lists these factors as including multiple sale of the same piece of land by different family members, the nefarious activities of land speculators, increasing landlessness of the poor as they sold off their lands, and the difficulty of obtaining land for infrastructure and development in the south in the post-independence era. ${ }^{36}$ What Mabogunje fails to highlight is what many Nigerians suspected and events subsequent to the promulgation of the decree confirmed those fears: The emergent elite that replaced the British colonial masters was seeking an easy and cheap avenue of amassing vast expanses of land. A testament to this is the multitudinous vast lands acquired by Gen Obasanjo in different parts of the country for his personal businesses. ${ }^{37}$ The pattern of land grabbing that TheNews magazine alleged was carried out by Gen Obasanjo has become a global phenomenon.

\section{LAND CRISES AND INJUSTICE IN NIGERIA}

The entrenchment of some of the colonial practices in the post-colonial era aggravated (not assuage) land crises. This all leads to one big problem, the injustice of dispossession of the most vulnerable members of the society, which eventually renders them landless. There are three major ways in which this takes place, namely, voluntary sale of land, violent displacement by arm militia, and forceful take over by government.

Shortly after the promulgation of the Land Use Decree in 1977, the military returned power to civilians in 1979. For a short time there was free flow of money from the hands of politicians and public office holders. Therefore, there was increased desire for investment and property development, and hence the demand for land. The oil gloat and subsequent drop in oil prices in the early 1980s brought about a slump in the economy. This situation coupled with the squandermania that characterized the second republic made the adoption of austerity measure inevitable. This, along with massive rigging of the 1983 general elections, led ineluctably to another military coup. The emergent military regime of Gen Mohammadu Buhari adopted a corrective stance, and there was massive retrenchment of public servants. Many of these retrenched people had to return to their rural roots to find ways of etching out a living from the land, bringing about greater competition for land in the rural areas.

By the late 1980s into the early 1990s, the military regime of Gen Babangida had embraced IMF's Structural Adjustment Program (SAP), with its adoption of neoliberal economic policies that called for the removal of subsidies on all sectors of the economy, privatization or commercialization of public services, and ultimately further retrenchments. Peters observes, "The severe retrenchment demanded under structural adjustment sent many people 'back to the land' for food and income, so putting even more pressure on rural land resources." 38 This was the era in which the sale of land grew astronomically. Alongside with this was also the phenomenal rise in conflicts overland ranging from family matters to community, clan or even inter-ethnic conflicts. Some of the very fiercely bloody communal clashes Nigeria has ever seen occurred during this period. Examples of these include the Zangon-Kataf crisis between the ethnic Kataf and Hausa of 1991 as well as another eruption in the perennial Tiv-Jukun clashes that lasted from 1990 to 1993 (which coincidentally abated with the end of the Babangida regime).In a study of population growth and land related crises in Tivland, Fanan Ujoh shows (using analysis of variance) from 1951-2007, the period with the highest land crises was period 1987-1997. ${ }^{39}$ Highlighting the havoc wrecked during Tiv-Jukun crises, Moses T. Aluaigbo writes "Maier states that the '1990/93 crises recorded widespread devastation; burnt out villages, littered corpses in various stages of decomposition and household items thrown all over' (cited in Alubo, 2006: 105)." 40

${ }^{35}$ Mabogunje, "Land Reform in Nigeria," 2-3.

36Mabogunje, "Land Reform in Nigeria," 3.

37 "Cover Story: The Amazing Wealth of OBJ-TheNews," Reproduced by Sahara Reporter on May 27, 2007, online at: http://saharareporters.com/2007/05/29/cover-story-amazing-wealth-obj-thenews accessed 12/12/2014.

38Peters, "Conflicts over Land," 5.

${ }^{39}$ FananUjoh,"Population Growth and Land Resource Conflicts in Tivland, Nigeria," Resources and Environment 4:1 (2014): 67-78.

${ }^{40}$ Moses T. Aluaigba, "The Tiv-Jukun Ethnic Conflict and the Citizenship Question in Nigeria," A Paper for the Aminu Kano Centre for Democratic Research and Training, Bayero University, Kano, p. 3. Accessed on 28/02/2015. Online at: http://www.ifra-nigeria.org/IMG/pdf/Moses T- ALUAIGBA The Tiv-Jukun Ethnic Conflict and the Citizenship Question in Nigeria.pdf

DOI: 10.9790/0837-2109123850 $\quad$ www.iosrjournals.org $45 \mid$ Page


The 1990s saw the ushering in of a global wind of change from authoritarian regimes to popular democracies. Africa was not left out by the hurricane-like wave of movement toward democratic governance that was sweeping across the globe in this period. Throughout Africa, transition programs were instituted for changing from military dictatorship (that had hitherto dominated the African political terrain for most of the post-colonial) to democracy. However, N. Chinyere Alimba observes that the democratic experience has created the avenue for the intensification of old crises and the generation of new ones. Commenting further on this she writes,

Nigeria, as the most populous country in Africa, shares the sentiment of harbouring varied magnitudes of conflicts, since the emergence of democracy in 1999, preventing citizens from enjoying its dividends in real terms. ... The manifestations of electoral conflict, ethnic conflict, religious conflict, herderfarmer conflict, communal conflict, and indigene/settler conflict have become brazen characteristics of the democratic development in Nigeria. ${ }^{41}$

To buttress the point, Joseph S. Gbenda observes that between 2000 and 2003, there were over 45 cases of interstate and intra-state land-related conflicts within the north-central Nigerian region consisting of the states of Benue, Taraba, Nasarawa, Plateau, Niger, Kwara, Kogi, and the southern parts of Kaduna and Bauchi states. ${ }^{42}$ Things have become worse since then. Some of the conflict that erupted or resurface since the return to civil rule in 1999 in Nigeria include the following, namely, the communal land conflict in Obubra Local Government Area of Cross River State; communal crises between Ezza/Ezillo groups in In Ebony State; the Eyo Abasi and Idua communal crisis over oil rich parcel of land in Akwa Ibom State; Eleme-Okrika crisis in Rivers State; Itsekiri-Ijaw/Urhobo crisis in Delta State; Aguleri-Umuleri land crisis in Anambra State; the Ife-Modakeke crisis in Osun State; the Ijaw-Ilaje conflict over oil rich parcels of land in Ondo State; the Chamba-Kuteb in Taraba State; the crises among the Assakio, Obi and Odobu communities in Lafia Local Government Area of Nasarawa State; Tiv farmers and nomadic Fulani clashes in Benue and Nasarawa States; and Fulani pastoralists and Gwari farmers land crisis in Gwako village in Gwagwalada Area Council of the Federal Capital Territory. ${ }^{43}$

While different reasons account for this phenomenon, the issue of land remains the most critical. ${ }^{44}$ This is evident even from the discussion of the issue by Alimba. ${ }^{45}$ A number of factors account for the explosion in the assortment of land crises in Nigeria since the return to civil rule in 1999, not the least being that the democratic set up affords people greater opportunities of free speech and self-determination. Besides, more people have access to more money and the purchase of land has increased and hence the increase in disputes over land. Additionally, government decisions for citing important projects, especially on border areas tend to also exacerbate land ownership crises. Finally, there has been phenomenal population growth. ${ }^{46}$ This has increased the pressure on and the demand for land and naturally this will increase the number of conflicts that arise from ownership claims on land.

There have been two new dangerous trends to land issues in the lost fifteen years. First, there is the menace of nomadic Fulani cattle herder attacks and takeover of sedentary farmer lands. There appears to be a

${ }^{41}$ N. ChinyereAlimba, "Probing the Dynamic of Communal Conflict in Northern Nigeria," Africa Research Review 8:1, \#32 (January 2014):177-204 [179]. Accessed 01/03/2015. Online at http://www.ajol.info/index.php/afrrev/article/view/101340.

42 Joseph S. Gbenda, "Age-Long Land Conflicts in Nigeria: A Case for Traditional Peacemaking Mechanisms," Ubuntu 1: 1\& 2 (2012): 159. Accessed on 28/02/2015 online at:

${ }^{43}$ Alimba, "Probing the Dynamic of Communal Conflict in Northern Nigeria," 185-86.

${ }^{44}$ Highlighting the centrality of land in the communal conflicts he surveyed in southwestern Nigeria, Albert Ayorinde Abegunde writes, "The above mentioned arguments reveal that land is central to continuity of life, indispensable in physical development and complex in social relations of production in the economic world. In other words, to every land, there is the socio-cultural dimension to it. As a result, conflict over land is often combined with strong economic, spatial, cultural and emotional values. There are indications that man's complex socio-economic, cultural and physical attachments to land have placed land in a sensitive and unique position. Conflict interests among communities to secure territories, conserve socio-economic resources and carry out physical development activities and practice customs and traditions on land have given birth to untold crises over the ages" ("Land as the Main Cause of Intercommunal Conflicts in Africa; Key Natural Resource against Community Development of Third World Nations?" Journal of Economics and Sustainable Development 2:4 (2011): 285-97 [285-86]. Accessed 02/03/2015 online at: www.iiste.org/Journals/index.php/JEDS/article/viewFile/455/339).

45 The numerous sources cited by Alimba all point the preponderance of land or resource control as the major cause of communal clashes in most of Nigeira ("Probing the Dynamic of Communal Conflict in Northern Nigeria," 186-90).

${ }^{46}$ For a fuller discussion of this see Ujoh, "Population Growth and Land Resource Conflicts in Tivland, Nigeria," 67-78. 
tacit collaboration between the federal government of Nigeria and the powerful northern Nigeria Fulani powerbrokers to expropriate the lands of the largely peasant farmer populations of the minority ethnic groups of central Nigeria (a region politically referred to as the Middle Belt). Beginning with the turn of the new millennium, hordes of marauding Fulani cattle herders armed with sophisticated small fire arms have continue to traverse the Middle Belt region, maim and kill its people, destroy their property and take over their lands. Writing on this issue Marietu S.Tenuche and Olarewaju O.Ifatimehin state, "A high percentage of conflicts arising from land disputes have to do with land matters and conflict between Fulani herdsmen and farmers over grazing land. ... As already noted in the paper, the various conflicts that ensued between Fulani herdsmen and farmers arose from the destruction of farm lands by herds of cattle," and their conclusion is that government has not do enough to address the problem. ${ }^{47}$ To buttress the point of the futility of the feeble attempts by the minority ethnic groups to wade off the marauding Fulani invasion due to the collaboration with powerbrokers, one only needs to the refer to the Nigeria Military invasion, annihilation of hundreds of unarmed civilians, and the destruction and looting of their property in the infamous Zaki-Biam massacre of 2003. Aluaigba points out that the whole crisis began as a dispute between a Fulani cattle herder and a Tiv farmer, where the former had brought his cattle to graze in the farm of the latter. ${ }^{48}$ The complicity of the federal government of Nigeria in conflicts over land and power in the favor of the Hausa-Fulani majority ethnic group is also highlighted in the report of the study group commissioned by The Nigeria Stability and Reconciliation Program. Tracing the origin of the now perennial ethno-religious crises in Jos North, the report states, "The creation of Jos North, Jos South and Jos East LGAs out of the old Jos LGA, was seen as an attempt by the Federal Government, under General Ibrahim Babangida, to favor the Hausas and Fulanis. This did not go down well with the indigenous communities (Afizere, Anaguta and Berom) who viewed the development as part of an expansionist agenda on the part of the Hausas and Fulanis to dominate other minority ethnic groups." 49 The crisis that was generated from this singular act has spiraled into a see-saw dynamic of attack and counter-revenge attack between these two feuding communities for over three decades now.

Secondly, since the advent of the so-called democratic experiment in the last two decades in Africa, there has been increasing flow of capital from the West to Africa. Since land is a cardinal factor of production, large scale investments (especially, in agriculture) are concomitant with large scale land acquisitions. Writing on this global phenomenon, Akachi Odoemene observes, "Recent figures from Oxfam showed that an area the size of London was being sold to investors every six days. Sub-Saharan Africa is the most common destination for such investments, accounting for over $60 \%$ of the global foreign land deals, while $62 \%$ of about 1217 publicly reported land deals across the world - covering a total area of about 56.2 million hectares - are located in the region." ${ }^{50}$ The argument for this is that foreign direct investments (FDIs) are indispensable for the development of the continent, and especially its rural areas. Odoemene points out that the development mantra used for this forms of land grabs ${ }^{51}$ is based on thin evidence, while on the contrary, evidence from recent research show that "most of these investments raise serious concerns as they are conducted in ways which disrespect and abuse people's rights, livelihoods and resources."

Odoemene lists the fundamentals of just land acquisition, which when absent means the transaction is a land grab. These include free, prior and informed consultation with local land owners, and the voluntary and

${ }^{47}$ Marietu S. Tenuche and Olarewaju O. Ifatimehin, "Resource conflict among farmers and Fulani herdsmen: Implications for resource sustainability," African Journal of Political Science and International Relations 3:9 (September 2009): 360-364 [361].

${ }^{48}$ Aluaigba, "The Tiv-Jukun Ethnic Conflict," 4-5.

${ }^{49}$ Nigeria Stability and Reconciliation Program "Watching Us Die on CNN" (The Report on the Study of Community-Level Conflict Management Mechanisms in the Niger Delta, Middle Belt and North East, Zones of Nigeria; Volume 1: Analytical Report), 58. Indeed, the despondency of the respondents towards the Nigerian government in the report is vividly captured in the quote from one of the respondents (from which the study got its title), "The Nigerian government has answer to these issues but they enjoy to see us dying, while they sit back in the reserve mansion. Watch us die on CNN" (p. 58).

${ }^{50}$ Akachi Odoemene, "Rethinking 'Development Investment' in Nigeria's Agricultural Land," in Gobal Economic Governance Policy Brief (August 2014), n.p. Accessed 3/3/2015 online at: http://www.globaleconomicgovernance.org

51 Explaining what constitutes "land grab," Odoemene says it is "the forced acquisition of land without valid consent and reasonable commitment to the future survival of the dispossessed. Under this definition, most recent large-scale land acquisitions are, in fact, land grabs. The processes undertaken by most of the investors, acting in concert with government officials and the local elite, often exclude and/or marginalise the land-holding locals" ("Rethinking 'Development Investment' in Nigeria's Agricultural Land," (emphasis added) n.p.

52 Odoemene, "Rethinking 'Development Investment' in Nigeria's Agricultural Land," n.p. 
non-coerced engagement of local land holders. I will also add that such transaction must ensure the security of the livelihood of those trading off their land, which in most cases is the main means of sustenance of the landholders. More often than not, the wealthy land buyers (private and corporate) are in league with powerful government functionaries, traditional rulers, and local power brokers, and as a team, work against the interest of the powerless peasant land owners. Out of the many examples that are found throughout Nigeria, poignant case studies include the land acquisition for Shonga Farms in Kwara State, Dominion Farms in Taraba State, ${ }^{53}$ and Wilmar International Farms in Cross River State.$^{54}$ In all of these cases, scores of local landholders were forcibly ejected from their ancestral lands, little or no compensations provided, and the future survival of the displaced persons were never factored into any of the deliberations. While the big projects themselves are put forward as examples of great economic development and attraction of foreign investments, in reality they work to entrench greater injustice, poverty, hunger, deprivation, and hardships for local populations.

\section{TRAJECTORIES OF CONNEXION BETWEEN DEUTERONOMIC LAND ECONOMY AND THE NIGERIAN SITUATION}

As we wrap up this discourse, it is pertinent at this point to pull together the connecting threads that interweave both the ancient Israelite and contemporary Nigerian contexts. On the basis of these, in view of Deuteronomic legislation vis-à-vis the realities of our times, I will make recommendations toward just and equitable approaches for land administration. These trajectories include:

1. Land in both contexts has deep spiritual significance. For the Israelites, the land was Yahweh's and they were only enjoying his beneficence, and they had to live on it in such ways as not to incur his wrath or curse, but secure his blessings. For traditional African societies, the ancestors and native gods (like the gods or goddesses of the earth/land) superintend over land and it must be treated with caution so they would not be angered (with the attendant visitation of disaster).

2. The ancestral patrimonial status of land in both contexts: For the Israelites, the land was the heritage of Yahweh, promised to the patriarchs that was inherited by allotment to the tribes and father's houses, and had to be kept perpetually within these lines. Similarly, for the Africans, land is handed down from one generation to another, and should remain within the lineage of their forebears.

3. Similarity of land tenure systems: for both ancient Israel and traditional African societies, land belongs to the kin-lineages within the tribal systems. In other words, community has the right of ownership of land in both contexts, while individual families possess the right of usage of the land.

4. Non-permanent alienation of land is common to both contexts.

5. Wealth, prosperity, and exploitation: In both contexts, we have seen the rise of oppression and exploitation accompanying increasing wealth.

6. The ultimate manifestation of oppression and exploitation is the expropriation of land from the poor and powerless by the powerful and prosperous.

\section{RECOMMENDATIONS}

In the view of the foregoing discussion, I hereby humbly submit the following recommendations as an alternative approach to addressing the injustices and inequities concomitant with the way land administration is being carried on with in contemporary context Nigeria:

1. The chief Nigerian land law, the Land Use Act, urgently needs to be amended, first by removing it from the constitution. The enshrining of a particular law into the constitution is not the right thing do. All laws ought to be subservient to the constitution, and to elevate one law and make it at par with the constitution, so that it is almost impossible to amend it does not augur well for the Nigerian people, especially for a law that affect the livelihood of all the citizens. Land is related to a people's cultural, social, and spiritual lives as well as their

53 For a further narration of this particular case, see

“Nigerian Farmers Displaced by US Company's Land Grab," This Day, Saturday 28 February, 2015, p. 1-2, Accessed 5/3/2015, online at: http://www.thisdaylive.com/articles/nigerian-farmers-displaced-by-us-company-s-land-grab/200522/

${ }^{54}$ Specifically, Odoemene notes that in "Gasol community, 45,000 people were evicted when 30,000 hectares of community land were leased to Dominion Farms. In Shongaland, 1,289 local farmers in 28 communities were uprooted to make way for foreign farmers, invited by the government, who were given 200,000 hectares of choice agricultural land" ("Rethinking 'Development Investment' in Nigeria's Agricultural Land," n.p. 
economy. All of these facets of life are dynamic. Thus, land laws must be allowed space for nimbleness so they could respond to the dynamism of the life of the people.

2. Strengthen communal control of land rather than vesting it in governments or traditional rulers. When (1) above is implemented, part of the amendment to the Land Use Act should be to divest the land in the governor of a state, as the Land Use Act provides now. The law should provide for freehold (absolute private ownership) in the urban areas, while it should entrench the tradition communal ownership system in the rural areas in line with our culture, customs, and traditions.

3. Recognition of native rights to land and limitation of encroachments thereupon without the outright authorization of native communities. Following (2) above, government should recognize the ownership rights of communities and the rights of usage by individuals which is germane to most Nigerian cultures. By this, it should be with absolute sense of responsibility that government would invoke overriding public interest (or eminent domain) for takeover of private lands. Whenever that is to happen, adequate compensation (not just compensation on the improvements on the land, as provided for in the Land Use Act) should be paid the people thus affected. Otherwise, on no account should the land of any person or community be takeover so as to be handed it over to another individual or corporation without prior negotiation with the native owners.

4. Large scale acquisition of native lands must include some form of partnership in which the natives have a fair share in whatever investments that are being made on the land. Land is a very critical factor of production (alongside of capital, labor, intellectual capital, and entrepreneurship). Thus, anyone bringing the other four components must recognize that the local community from who land is being acquired is offering a critical component for whatever enterprise that will be set up on it. Therefore, they should be reckoned with as stakeholders in the enterprise and the true value of the land should be calculated and deemed as their stake in the enterprise on which they would receive dividends that accrue on it accordingly.

5. In line with traditional African land tenure system, the amended Land Use Act should legislate against permanent transfer of rural lands. Instead, only right of usage should be what is acquired. In the spirit of jubilee, once the person who has so acquired the right to the usage of the land does not need it anymore, it should revert back to the community that owns it and to individuals that have the right of usage of the land.

\section{CONCLUSION}

In this paper, using the contextual study approach, I have surveyed the ideal land economy as envisaged by YHWH in the Torah as well as the reality of the situation in Israel in the eighth century before the Common Era. I also explored the situation of land administration in Nigeria. In both contexts of ancient Israel and contemporary Nigeria, I observed similarities both in land tenure systems and patterns of exploitation and oppression of the powerless. On the basis of observed connexity between these contexts, the ideals envisaged in the Torah were appropriated and fashioned into recommendations that will ensure a just system of land administration in Nigeria.

\section{BIBLIOGRAPHY}

[1] Abah, Hope. "Tiv Will Not Release Land for Cattle Grazing Reserves-Tor Tiv.” Daily Trust. 28 April. [Online.]Retrieved from: http://www.dailytrust.com.ng/daily/news/22638-tivs-will-not-release-land-forgrazing-reserves-tor-tiv.Accessed December 02, 2014.

[2] Abegunde, A.A. "Land as the Main Cause of Inter-communal Conflicts in Africa; Key Natural Resource against Community Development of Third World Nations? Journal of Economics and Sustainable $\begin{array}{llll}\text { Development } & 2: 4 & \text { (2011): } & \text { [Online.]: }\end{array}$ www.iiste.org/Journals/index.php/JEDS/article/viewFile/455/339. March 02, 2015.

[3] Abogun, James. "The Middle Belt People of Nigeria." [Online.]Retrieved from: http://www.thenigeria.com/2011/11/middle-belt-people-of-nigeria.html\#.VHqXtTHF8mM. November 30, 2014.

[4] Agbese, Pita Ogaba. Ethnic Conflict and Hometown Associations: An Analysis of the Experience of the Agila. Africa Today 43:2 (1996):139-53.

[5] Alimba, N. Chinyere. Probing the Dynamic of Communal Conflict in Northern Nigeria. Africa Research Review 8:1 (2014):177-204. Online at http://www.ajol.info/index.php/afrrev/article/view/101340. March 01, 2015.

[6] Aluaigba, Moses T. "The Tiv-Jukun Ethnic Conflict and the Citizenship Question in Nigeria." Aminu Kano Centre for Democratic Research and Training, Bayero University, Kano, 2008. [Online.]Retrieved from: http://www.ifra-nigeria.org/IMG/pdf/Moses_T-_ALUAIGBA_-_The_TivJukun_Ethnic_Conflict_and_the_Citizenship_Question_in_Nigeria.pdf . February 28, 2015.

[7] Gbenda, Joseph S. "Age-Long Land Conflicts in Nigeria: A Case for Traditional Peacemaking Mechanisms." Ubuntu 1:1\& 2 (2012):159. [Online.]Retrieved from: http://reference.sabinet.co.za/sa_epublication_article/aa_ubuntu_v1_n1_2_a7 . February 03, 2016. 
[8] Glass, Zipporah G. "Land, Slave Labor and Law: Engaging Ancient Israel's Economy.” JSOT 91 (2000): 27-39.

[9] Harrison, R. K. Introduction to the Old Testament. Grand Rapids: Eerdmans Publishing Company, 1969.

[10] Hill, Andrew E. “The Ebal Ceremony as Hebrew Land Grant?” JETS 31:4 (1988): 399-406.

[11] Kandawire, J. A. K. "Thangata in Pre-colonial and Colonial Systems of Land Tenure in Southern Malawi with Special Reference to Chingale." Africa 47:2 (1977):185-91.

[12] Lentz, C. "Is Land Inalienable? Historical and Current Debates on Land Transfers in Northern Ghana."Africa 80:1 (2010):56-80.

[13] Lohfink, Norbert, S.J. Poverty in the Laws of the Ancient Near East and of the Bible. Theological Studies 52 (1991):34-50.

[14] Longman III,Tremper. (ed.). The Baker Illustrated Bible Dictionary. Grand Rapids: Baker, 2013.

[15] Mabogunje, Akin L. Land Reform in Nigeria: Progress, Problems \& Prospects. A Paper Presented to the Presidential Technical Committee for Land Reform, Abuja, 2009.

[16] McComiskey, Thomas Edward. "Amos: Introduction and Commentary." Pages 267-331 in Frank E. Gaebelein (ed.). The Bible Expositor's Bible Commentary, vol. 7 of 12 Vols. Grand Rapids: Zondervan Publishing House, 1985.

[17] Miller, Jr., Patrick D. "The Gift of God: The Deuteronomic Theology of the Land.” Int 23 (1969): 45165.

[18] Nicholson, E. Deuteronomy and Tradition. Philadelphia: Fortress Press, 1967.

[19] Nigeria Stability and Reconciliation Programme "Watching Us Die on CNN." The Report on the Study of Community-Level Conflict Management Mechanisms in the Niger Delta, Middle Belt and North East, Zones of Nigeria; Volume 1: Analytical Report, 58. 2012. [Online.] Retrieved from: http://www.nsrpnigeria.org/wp-content/uploads/2013/11/CCMM-Vol-1-Reports-6.12.12.pdf. February 03, 2016.

[20] Obioha, E.E. Change in Tenure Pattern and Customary Land Practices among Igbo Community in Southeastern Nigeria. Anthropologist 10:1 (2008):45-53.

[21] Odoemene, Akachi. 2014. Rethinking 'Development Investment' In Nigeria's Agricultural Land. In Gobal Economic Governance Policy Brief. [Online.]: Http://Www.Globaleconomicgovernance.Org. March 3, 2015.

[22] Peters, Pauline E. "Conflicts over Land and Threats to Customary Tenure in Africa Today." CID Working Paper No. 247. Working Papers Series of Center for International Development at Harvard University, 2012.

[23] Pitkänen, Pekka. "Dr. Jekyll and Mr. Hyde? Deuteronomy and the Rights of Indigenous Peoples."Political Theology 11:3 (2010):399-409.

[24] Richter, Sandra. "Environmental law in Deuteronomy: One Lens on a Biblical Theology of Creation Care." BBR 20:3 (2010):356.

[25] Stone, Glenn Davis. "'Predatory Sedentism': Intimidation and Intensification in the Nigerian Savanna.Human Ecology 25:2 (1997): 223-242.

[26] Tenuche, Marietu S. and Olarewaju O. Ifatimehin. "Resource conflict among farmers and Fulani herdsmen: Implications for resource sustainability." African Journal of Political Science and International Relations 3:9 (2009): 360-364.

[27] Tushima, C. T. A. The Fate of Saul's Progeny in the Reign of David. Eugene, OR.: Pickwick Publications, 2011.

[28] Ujoh, Fanan. "Population Growth and Land Resource Conflicts in Tivland, Nigeria. "Resources and Environment 4:1 (2014):67-78.

[29] Wildberger, C. H. "Israel un Sein Land.” EvTh XVII (1956):420-22.

[30] Weinfeld, M. "The Covenant of Grant in the Old Testament and the Ancient Near East." JAOS 90 (1970):184-203.

[31] THENEWS. Cover Story: The Amazing Wealth of OBJ. Reproduced by Sahara Reporter on May 27 , 2007. [Online.]Retrieved from: http://saharareporters.com/2007/05/29/cover-story-amazing-wealth-objthenews.Accessed December 12, 2014.

[32] This Day. "Nigerian Farmers Displaced by US Company's Land Grab.” 28 February, 2015, p. 1-2.online at: $\quad$ http://www.thisdaylive.com/articles/nigerianfarmersdisplacedbyuscompanyslandgrab/200522/. Accessed March 05, 2015. 